\title{
Motility of the reticulum and rumen of sheep given juice-extracted pasture
}

\author{
BY L. M. MCLEAY, D. C. KOKICH AND H-U. HOCKEY \\ School of Science, University of Waikato \\ AND T. E. TRIGG \\ Ruakura Animal Research Station, Hamilton, New Zealand
}

(Received 3 February 1981-Accepted 6 July 1981)

1. Sheep were fed on different diets of juice-extracted herbage to determine what effect juice-extraction had on reticulo-rumen motility.

2. The frequency of $\mathrm{A}$ and $\mathrm{B}$ sequences of contraction of the reticulo-rumen were recorded during eating, rumination and inactivity for continuous periods of $24-72 \mathrm{~h}$ by using integrated electromyograms obtained from electrodes implanted in the musculature of the reticulum and cranial dorsal rumen.

3. Animals were fed on herbage in which approximately $200 \mathrm{~g} / \mathrm{kg}$ dry matter had been removed in juice extracted from ryegrass (Lolium perenne), white clover (Trifolium repens), mixed ryegrass-white clover and lucerne (Medicago sativa).

4. Over all the frequency of A sequences of contraction did not differ in animals fed on pressed herbage or the unpressed material from which it was derived, although it was slower during rumination on some of the pressed material. In contrast, the frequency of B sequences was higher on the pressed material. The frequencies of contraction of A and B sequences in animals fed on pressed herbage was related to the activity of the animals in the order eating $>$ rumination $>$ inactivity.

5. Changes in reticulo-rumen motility due to juice extraction were small and the frequencies of $A$ and $B$ sequences of contraction in sheep fed on pressed herbage were in the range encountered in ruminants consuming more conventional foods.

Recently, investigations have been made on the extraction of protein from New Zealand lowland pasture with a view to integrating a protein recovery process into the pastoral farming system (Donnelly \& McDonald, 1978). Extraction of protein from pasture using this process removes approximately $200 \mathrm{~g} / \mathrm{kg}$ dry matter (DM) harvested and the fibrous material remaining is a major by-product. The nutritive value of this product termed pressed pasture (PP) has been investigated in terms of its use in supporting lactating dairy cows. Preliminary experiments showed that animals offered PP produced less milk with lower fat and protein concentrations than those fed on pasture and the diminished production was associated with reductions in both intake and apparent digestibility of nutrients (Trigg \& Bryant, 1979). Possible reasons for a reduced food intake have been investigated, and included the present study on the effect of PP on gastric motility. In these experiments PP derived from ryegrass (Lolium perenne) white clover (Trifolium repens) and lucerne (Medicago sativa) was fed to sheep and its effect on reticulo-rumen motility examined using the gastric electromyogram as an index of motility.

METHODS

\section{Animals and management}

Three Perindale rams and three South Suffolk wethers aged 1 year and ranging in weight from 50 to $66 \mathrm{~kg}$ were kept indoors in individual metabolism crates and fed ad lib. Uneaten herbage from the previous day was removed between 08.30 and 09.30 hours daily and new herbage presented to each animal. Water and a salt block lick were available at all times. 


\section{Diets and processing}

The grasses fed to the sheep were perennial ryegrass, white clover and lucerne. Sheep nos. 1, 2 and 3 were fed on pressed ryegrass harvested in the autumn (PAR), pressed ryegrass harvested in the spring (PSR), pressed clover harvested in the spring (PSC), pasture (P1) and pressed pasture (PP1). Sheep nos. 4, 5 and 6 were fed on pasture (P2), pressed pasture (PP2), lucerne (L) and pressed lucerne (PL). The pasture forages consisted of grass cut from a mixed ryegrass-white clover sward harvested in spring (P1) and summer (P2). Pressed pasture and lucerne were processed from their corresponding unpressed forage. All forages were cut between 5 and 8 weeks of growth and PSR and P2 were cut from rank stands of grass having a higher proportion of stem material than the other forages.

The forages were cut with a flail harvester, processed, packed in $10 \mathrm{~kg}$ portions, quick-frozen and stored at $-18^{\circ}$ on the same day as harvest. The methods employed in packaging, quick-freezing and storage were those reported by Hutton et al. (1975). Before feeding, the $10 \mathrm{~kg}$ blocks were thawed overnight by standing at room temperature.

Processing of forages involved the methods described by Swan et al. (1980). The DM content of the forgage was reduced to $100 \mathrm{~g} / \mathrm{kg}$ by the addition of water so as to facilitate juice expression. The forage was then pulped in a rotary pulper consisting of a shaft studded with steel beater rods rotating at $3500 \mathrm{rev} . / \mathrm{min}$ within a $300 \mathrm{~mm}$ steel cylinder. With PAR, PSR and PSC the pulp was then squeezed in a belt press similar to that described by Connel \& Foxell (1976). For pasture and lucerne the pulped forage was dejuiced using a screw-press designed and built at Ruakura Agricultural Research Centre (Mills et al. 1980). Juiceextraction removed approximately $200 \mathrm{~g} \mathrm{DM} / \mathrm{kg}$ and $300 \mathrm{~g}$ protein $/ \mathrm{kg}$ from the original material. A chemical analysis of pasture and pressed pasture showed that juice-extraction resulted in a general reduction of all chemical constituents except for mild-acid-detergent fibre which increased (Trigg \& Bryant, 1978). They pointed out that due to the dependence of the extraction process on moisture content it was likely that much of the water-soluble fraction of each nutrient was removed.

\section{Feeding regimen}

The sheep were fed on each diet for a number of days before recording commenced. This varied from a minimum of $9 \mathrm{~d}$ with PAR to $23 \mathrm{~d}$ with PSR. Feeding was ad lib. under the conditions described previously. In those experiments in which comparisons of pressed and unpressed material were made pressed material was given first so that the amount of unpressed material could be restricted to similar DM intakes if necessary. The DM content was determined by drying triplicate $500 \mathrm{~g}$ samples of the food to a constant weight at $100^{\circ}$. The DM content of the herbages and the DM intakes of the sheep are presented in Table 1.

Motility of the reticulum and rumen of sheep nos. 1, 2 and 3 was recorded over a period of 7 months and sheep nos. 4, 5 and 6 for a period of 4 months after which time an autopsy was carried out to inspect the electrodes.

\section{Surgical and recording procedures}

The gastric electromyogram (EMG) was used as an index of motility and was obtained based on the method of Ruckebusch (1970) as modified by Titchen (1979). Stainless-steel electrodes were implanted in the reticulum and cranial dorsal rumen under Halothane BP (Fluothane, ICI, Cheshire, UK) anaesthesia and employing fully aseptic conditions.

Electromyograms were obtained by recording between two electrodes and using AC 3540 high-gain amplifiers and 3542 function units (time constant $0 \cdot 1 \mathrm{~s}$ ) in conjunction with a 6 channel M19 chart recorder (Devices, Welwyn Garden City, UK). The activity obtained corresponded to contractions of the reticulum and rumen as validated by Ruckebusch 
Table 1. Dry matter (DM) content of herbages and DM intakes of sheep on recording days

\begin{tabular}{|c|c|c|c|}
\hline Herbage & DM $(\mathrm{g} / \mathrm{kg})$ & Sheep no. & $\begin{array}{l}\text { Mean DM intake } \\
(\mathrm{g} / \mathrm{d})\end{array}$ \\
\hline PAR & 15.5 & $\begin{array}{l}1 \\
2 \\
3\end{array}$ & $\begin{array}{l}1267 \\
1432 \\
1309\end{array}$ \\
\hline PSR & $23 \cdot 0$ & $\begin{array}{l}1 \\
2 \\
3\end{array}$ & $\begin{array}{r}1078 \\
1324 \\
788\end{array}$ \\
\hline PSC & $16 \cdot 7$ & $\begin{array}{l}1 \\
2 \\
3\end{array}$ & $\begin{array}{l}1878 \\
1983 \\
1380\end{array}$ \\
\hline P1 & $16 \cdot 2$ & $\begin{array}{l}1 \\
2 \\
3\end{array}$ & $\begin{array}{l}1714 \\
1469 \\
1259\end{array}$ \\
\hline PP1 & $16 \cdot 6$ & $\begin{array}{l}1 \\
2 \\
3\end{array}$ & $\begin{array}{l}1796 \\
1961 \\
1572\end{array}$ \\
\hline P2 & $21 \cdot 4$ & $\begin{array}{l}4 \\
5 \\
6\end{array}$ & $\begin{array}{l}1650 \\
1547 \\
1579\end{array}$ \\
\hline PP2 & $20 \cdot 1$ & $\begin{array}{l}4 \\
5 \\
6\end{array}$ & $\begin{array}{l}1602 \\
1524 \\
1432\end{array}$ \\
\hline$L$ & $15 \cdot 1$ & $\begin{array}{l}4 \\
5 \\
6\end{array}$ & $\begin{array}{l}1610 \\
1509 \\
1495\end{array}$ \\
\hline PL & $19 \cdot 6$ & $\begin{array}{l}4 \\
5 \\
6\end{array}$ & $\begin{array}{l}1991 \\
1532 \\
1641\end{array}$ \\
\hline
\end{tabular}

PAR, pressed autumn ryegress; PSR, pressed spring ryegrass; PSC, pressed spring clover; P1, spring pasture; PP1, pressed spring pasture; P2, summer pasture; PP2, pressed summer pasture; L, lucerne; PL. pressed lucerne.

(1970). Long-term recording of the gastric EMG was facilitated by integrating the EMG with a Devices 3520 integrator using a time constant of $2 \mathrm{~s}$. Clear, reliable and uniform recordings corresponding to $A$ and $B$ sequences (Reid, 1963) of contraction of the reticulum and rumen (Fig. 1) were obtained at least for up to 6 months following electrode implantation.

Jaw activity of the animals was recorded by means of a balloon fitted to a head harness and connected to a Devices physiological pressure transducer (Type 4-327-L221) used in conjunction with a Devices 3552 DC amplifier and M19 chart recorder. Periods of eating, rumination and inactivity were distinguished by this means and correlated with reticulorumen motility (Fig. 1).

Simultaneous recording of jaw activity, reticulum and dorsal rumen contractions allowed the determination of the frequency of contraction of the A and B sequences for each activity: eating $(E)$, ruminating $(R)$ and inactivity $(I)$ on the different foods. I was defined as those periods when the animal was not engaged in $\mathrm{R}$ or $\mathrm{E}$. These three activities were chosen as it has been noted by other workers (e.g. Reid \& Cornwall, 1959) that each activity has associated with it different frequencies of $\mathrm{A}$ and $\mathrm{B}$ sequences. The characteristic frequency of contraction associated with a particular activity may not be attained for several 


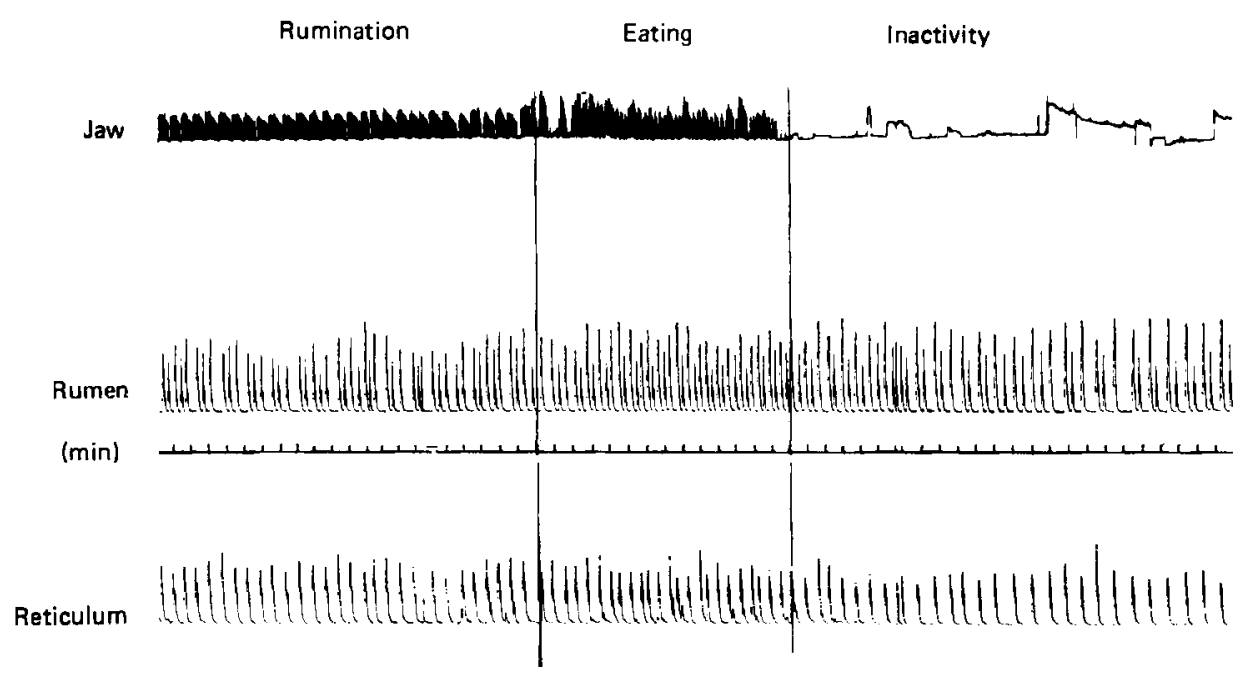

Fig. 1. A typical section of a recording from a sheep showing the activity of the animal as indicated by jaw movements, and the associated contractions of the reticulum and rumen recorded as integrated $(2 \mathrm{~s}$ time constant) electromyograms of these structures. Traces from above downwards: jaw movements, cranial dorsal rumen contractions, 1 min time signal, reticulum contractions.

minutes and for this reason bouts of an activity of less than 10 min were not considered in the calculations.

Recording was continuous for at least $24 \mathrm{~h}$ and in some instances was for up to $72 \mathrm{~h}$. An attempt was made to start each recording run at the time when new food was made available.

\section{Statistical analysis}

The basic statistic for comparative purposes was the 'average-rate' of contraction, calculated separately for the A and B sequences for each sheep in each activity. The reticulum and dorsal rumen traces were divided into bouts according to the activity (I, R or E) shown by the jaw record. The reticulum trace provided a count of the A sequence contractions and subtraction of this from the dorsal rumen contraction count provided the B sequence count. The A sequence average-rate of contraction was defined as the sum of the A sequence counts, for a particular sheep and activity, divided by the sum of the bout durations ( $\mathrm{min}$ ) from which the A sequence counts were derived. The same followed for the B sequence average-rate of contraction. This method had the effect of giving the longer bouts more weight as it was considered that the longer the bout the more representative value it would give of the characteristic frequency of contraction with each activity.

The recording procedure employed in these experiments allowed the accumulation of extensive data and in a typical recording run, for example, for one sheep on one food, the $A$ and $B$ sequences of contraction measured and used in the calculations were derived from: E, 24 bouts of 10-72 min duration; R, 30 bouts of 14-109 min duration; I, 24 bouts of 13-82 min duration.

An analysis of variance was carried out using weighted average-rates for the $A$ and $B$ sequences for the food combinations PAR, PSR and PSC, P1 and PP1, P2 and PP2, and L and PL. The weights were the sum of bout durations from which the particular average-rate was obtained. The analysis of variance was a split plot design replicated over the three sheep with foods as the main plot and activities as split plot treatments. The computer program 
Table 2. The average rates of $A$ and $B$ sequences (contractions/min) according to activity of sheep fed on pressed autumn ryegrass $(P A R)$, pressed spring ryegrass $(P S R)$, pressed spring clover $(P S C)$, spring pasture $(P 1)$, pressed spring pasture $(P P 1)$, summer pasture $(P 2)$, pressed summer pasture (PP2), lucerne $(L)$ and pressed lucerne $(P L)$

\begin{tabular}{|c|c|c|c|c|c|c|c|c|c|c|c|c|c|c|}
\hline Activity & $\begin{array}{c}\text { Herbage.... } \\
\text { Sequence }\end{array}$ & PAR & PSR & PSC & SED & P1 & PP1 & SED & P2 & PP2 & SED & $\mathbf{L}$ & PL & SED \\
\hline I & $\begin{array}{l}\text { A } \\
\text { B }\end{array}$ & $\begin{array}{l}1 \cdot 17 \\
0.83\end{array}$ & $\begin{array}{l}0.97 \\
0.61\end{array}$ & $\begin{array}{l}1 \cdot 19 \\
0.85\end{array}$ & $\begin{array}{l}0.06 \\
0.08\end{array}$ & $\begin{array}{l}1.07 \\
0.73\end{array}$ & $\begin{array}{l}1 \cdot 11 \\
0.84\end{array}$ & $\begin{array}{l}0.05 \\
0.06\end{array}$ & $\begin{array}{l}0.93 \\
0.66\end{array}$ & $\begin{array}{l}0.97 \\
0.69\end{array}$ & $\begin{array}{l}0.06 \\
0.04\end{array}$ & $\begin{array}{l}0.95 \\
0.65\end{array}$ & $\begin{array}{l}1.03 \\
0.74\end{array}$ & $\begin{array}{l}0.06 \\
0.09\end{array}$ \\
\hline $\mathbf{R}$ & $\begin{array}{l}\text { A } \\
\text { B }\end{array}$ & $\begin{array}{l}1.56 \\
0.97\end{array}$ & $\begin{array}{l}1.41 \\
0.77\end{array}$ & $\begin{array}{l}1.60 \\
0.93\end{array}$ & & $\begin{array}{l}1.38 \\
0.75\end{array}$ & $\begin{array}{l}1.41 \\
1.01\end{array}$ & & $\begin{array}{l}1.28 \\
0.73\end{array}$ & $\begin{array}{l}1.24 \\
0.74\end{array}$ & & $\begin{array}{l}1.32 \\
0.68\end{array}$ & $\begin{array}{l}1.15 \\
0.75\end{array}$ & \\
\hline E & $\begin{array}{l}\text { A } \\
\text { B }\end{array}$ & $\begin{array}{l}1.65 \\
1.35\end{array}$ & $\begin{array}{l}1.63 \\
1.36\end{array}$ & $\begin{array}{l}1.88 \\
1.53\end{array}$ & & $\begin{array}{l}1.73 \\
1.35\end{array}$ & $\begin{array}{l}1.76 \\
1.52\end{array}$ & & $\begin{array}{l}1 \cdot 53 \\
1.02\end{array}$ & $\begin{array}{l}1.53 \\
1.07\end{array}$ & & $\begin{array}{l}1 \cdot 60 \\
1 \cdot 10\end{array}$ & $\begin{array}{l}1.57 \\
1.20\end{array}$ & \\
\hline
\end{tabular}

I, inactivity; R, rumination; E, eating; SED, standard error of the difference between herbage means at the same activity or at different activities.

GLIM (General Linear Interactive Modelling) was used to carry out the analysis of variance (Baker \& Nelder, 1978).

The F-test at $P<0.05$ was used to test the null hypothesis: that the mean frequency of contraction for the unpressed material was equal to that of the pressed material. Similarly, equal mean frequencies were assumed in the null hypothesis for PAR, PSR and PSC. Three factors and their interactions were used to which variation could be attributed: $F$ (food), $\mathrm{S}$ (sheep) and $\mathrm{T}$ (activity).

\section{RESULTS}

\section{DM intake}

In these experiments an attempt was made to obtain comparable DM intakes (DMI) of the different foods on recording days particularly between the unpressed and pressed materials. It was expected that the animals would eat less of the pressed material and this was fed first in each instance. Generally intakes were comparable but in some instances the DMI was substantially greater with the pressed material than the unpressed, the most extreme example was sheep no. 2 fed on Pl and PPl (Table 1).

Over all the DMI of the pressed material was high apart from the herbage PSR which was cut from a rank sward and sheep no. 3 ate considerably less of this material (Table 1).

\section{Motility}

The average-rates for the $A$ and $B$ sequences of contraction of the reticulo-rumen of sheep fed on the different herbages are presented in Table 2. A summary of the factors and their interactions shown to be statistically significant is in Table 3 .

Animals fed on PAR, PSR and PSC. In animals fed on PAR, PSR and PSC there were significant differences in the frequency of $A$ sequences of contraction (Table 2) between activities (T), sheep (S) and foods (F) (Table 3). The highest frequencies occurred during eating and the lowest during inactivity. Sheep no. 3 had consistently lower frequencies of contraction than sheep nos. 1 and 2. The PSR produced distinctly lower frequencies of contraction than PAR and PSC (Table 2).

In contrast the $B$ sequences of contraction differed only with the activities of the animals 
Table 3. Summary of factors $F$ (food), $T$ (activity), $S$ (sheep) and interactions (FT) shown to be significant by the $F$ test at $\mathrm{P}<0.05$

\begin{tabular}{lcc}
\hline Herbage & A sequence & B sequence \\
\hline PAR, PSR and PSC & $\mathrm{F}+\mathrm{T}+\mathrm{S}$ & $\mathrm{T}$ \\
P1 and PP1 & $\mathrm{T}+\mathrm{S}$ & $\mathrm{F}+\mathrm{T}$ \\
P2 and PP2 & $\mathrm{T}+\mathrm{S}$ & $\mathrm{T}+\mathrm{S}$ \\
L and PL & $\mathrm{T}+\mathrm{S}+\mathrm{FT}$ & $\mathrm{T}+\mathrm{S}$ \\
\hline
\end{tabular}

PAR, pressed autumn ryegrass; PSR, pressed spring ryegrass; PSC, pressed spring clover; P1, spring pasture; PP1, pressed spring pasture; P2, summer pasture; PP2, pressed summer pasture; $L$, lucerne; PL, pressed lucerne.

(Table 3 ) and the frequency of contractions was in the order, eating $>$ rumination $>$ inactivity $(P<0.05)$.

Animals fed on unpressed and pressed herbage. In the experiments comparing the pressed material with the herbage from which it was derived there were significant differences between sheep and activities for the frequency of $A$ sequences for both the pastures and the lucerne (Table 3). There were no significant differences in the frequency of $A$ sequences between pressed and unpressed herbage when summed over all activities, but $A$ sequences were slower in frequency during rumination on PL (see interaction FT in Table 3). Sheep no. 6 had lower frequencies of contraction than sheep nos. 4 and 5 on all foods. The frequency of $A$ sequences for all foods was in the order, eating $>$ rumination $>$ inactivity $(P<0.05)$.

The frequency of B sequences of contraction showed a significant difference between $\mathrm{Pl}$ and PPl (Table 3), the frequency being higher on the pressed material (Table 2). Significant differences occurred between the frequency of B sequences with both pastures and lucerne according to activity in the order, eating $>$ rumination $>$ inactivity $(P<0.05)$. Differences between sheep in the frequency of B sequences occurred with P2 and PP2 and L and PL (Table 3), sheep no. 6 having lower frequencies than sheep nos. 4 and 5 .

\section{DISCUSSION}

The major finding of these experiments was that the frequency of A sequences of contraction of the reticulo-rumen did not differ significantly over all activities when sheep were fed on pressed herbage or the unpressed material from which it was derived. This included herbage of two mixed ryegrass-clover pastures and of lucerne. There was however a difference according to activity and during rumination the frequencies of $\mathrm{A}$ sequences were slower on one of the pressed materials (PL). Such a reduction could possibly be explained by an increase in the duration of mastication of each regurgitated bolus and this would be consistent with a higher fibre content of the pressed material when compared to the unpressed.

The frequencyof B sequences of contraction tended to be higher on the pressed material and the difference was significant in animals fed on P1 and PP1. An increase in the B sequences of contraction may be attributed to an increase in gas formation (Reid \& Cornwall, 1959; Reid \& Titchen, 1965). The situation in the present experiments may have been confounded by the sheep consuming more of the pressed material in some instances, but in others with similar intakes of pressed and unpressed material the frequency of $B$ sequences of contraction was still higher on the pressed material (see Tables 1 and 2). The reasons for this effect remain unknown and deserve further investigation. 
The most significant changes in the frequency of $\mathrm{A}$ and $\mathrm{B}$ sequences of contraction in animals fed on pressed herbage occurred in association with the activity of the animals. Both $\mathrm{A}$ and $\mathrm{B}$ sequences were highest in frequency when the animals were eating, lower frequencies occurred during rumination and the lowest during periods of inactivity. The same applied when the animals ate unpressed herbage and these observations correspond with those of Waghorn \& Reid (1977) for sheep fed on chaffed lucerne hay, lucerne pellets and fresh ryegrass. It therefore appears that extraction of juice from herbage does not eliminate the effect activity of the animal has on reticulo-rumen motility.

A further source of variation in these experiments was due to differences in the frequencies of A sequences of contraction between sheep. Sheep no. 3 had consistently lower frequencies than sheep nos. 1 and 2 but this did not apply to its B sequences. This animal ate less than the others and it is known that increased motility is associated with an increased intake (Freer et al. 1962). Similarly sheep no. 6 also had lower frequencies of A sequences than sheep nos. 4 and 5 and this occurred when it consumed similar amounts of DM as the others. Indications that there may be a genetic basis for differences in reticulo-rumen motility have been provided by studies on identical twins (Johns et al. 1958) and in the present work differences between animals have been taken into account by the analysis of variance.

Three different pressed herbages, PAR, PSR and PSC, were used to investigate their effects on gastric motility when animals ate the processed herbage. Significant differences in motility were obtained, but these were confounded by differences in the DMI. It was apparent that the animals discriminated against the PSR derived from a rank sward of grass and preferred the PSC (see Table 1). Clearly the juice-extraction process did not produce herbages of similar qualities.

Over all, changes in reticulo-rumen motility due to juice extraction were small and the frequencies of $A$ and $B$ sequences of contraction were characteristic of the range encountered in ruminants consuming more conventional foods.

The authors are indebted to the staff of the Nutrition Centre, Ruakura Animal Research Station, for the care and maintenance of the animals, and for the provision of pressed herbage. The use of the Station's experimental surgery is gratefully recorded.

\section{REFERENCES}

Baker, R. J. \& Nelder, J. A. (1978). The GLIM System, Release 3, General Linear Interactive Modelling Manual, Rothamsted Experimental Station, England: Numerical Algorithms Group.

Connel, J. \& Foxell, P. R. (1976). Bienn. Rev. Natl Inst. Res. Dairy p. 21.

Donnelly, P. E. \& McDonald, R. M. (1978). Proc. N.Z. Nutr. Soc. 3, 84.

Freer, M., Campling, R. C. \& Balch, C. C. (1962), Br. J. Nutr. 16, 279.

Hutton, J. B., Hughes, J. W., Bryant, A. M. \& Pluck, L. J. (1975). N.Z. Jl agric. Res. $18,37$.

Johns, A. T., Mangan, J. L. \& Reid, C. S. W. (1958). Proc. N.Z. Soc. Anim. Prod. 18, 21.

Mills, R. A., McDonald, R. M. \& Donnelly, P. E. (1980). Trans. N.Z. Inst. Eng. 7, 9.

Reid, C. S. W. (1963). Proc. N.Z. Soc. Anim. Prod. 23, 169.

Reid, C. S. W. \& Cornwall, J. B. (1959). Proc. N.Z. Soc. Anim. Prod. 19, 23.

Reid, C. S. W. \& Titchen, D. A. (1965). J. Physiol., Lond. 181, 432.

Ruckebusch, Y. (1970). J. Physiol., Lond. 210, 857.

Swan, J. E., Donnelly, P. E., McDonald, R. M., Mills, R. A., Ritchie, J. R. \& Trigg, T. E. (1980). Proc. Sth Pac Poult. Sci. Conv. Auckland, Oct. 1980, p. 44.

Titchen, D. A. (1979). J. Physiol., Lond. 292, 381

Trigg, T. E. \& Bryant, A. M. (1978). Proc. N.Z. Nutr. Soc. 3, 96.

Trigg, T. E. \& Bryant, A. M. (1979). Proc. Nutr. Soc. 38, 134A.

Waghorn, G. C. \& Reid, C. S. W. (1977). Proc. N.Z. Soc. Anim. Prod. 37, 176. 